\title{
CUSTOMER RELATIONS IN BUILDING VALUE FOR THE CUSTOMER IN COMMERCIAL ENTERPRISES
}

\begin{abstract}
The customer plays a key role in every company. He is the main revenue provider. The profitability of the business activity of a particular company depends on appropriate customer relations. The task of management accounting in a company is to work out such a method of estimating the profitability of customers that it supports management decisions in shaping profitable, long-term relations with customers. Customer perceived value is a tool to help determine customer requirements. The aim of the paper is to present a concept of customer perceived value in commercial companies. A critical review of literature and a method of deduction and induction were used to develop the article. The article contains proposals of using various variables to determine the customer perceived value.
\end{abstract}

Keywords: client, customer perceived value, relationships.

\section{INTRODUCTION}

Customers are the main source of revenue for every company. According to the Polish Language Dictionary, a client is "a person who buys something in a shop, uses the services of a bank, a lawyer, etc. or arranges a case in an institution"2. Other customer definitions can be found in marketing related items. According to them, the customer is "an individual or an institution acting as a seller's partner in the sale and purchase of goods or services" 3 . Everyone can be a customer ${ }^{4}$. However, customers are different. There are many customer classifications. The variables differentiating between the customers will have the impact on the costs of acquiring and servicing these customers.

Customers are elements of the company environment without which the creation of the company's value is not possible. For this reason, companies must provide them with goods and services that meet their expectations. Trading companies, in order to attract and retain customers, are 'doomed' to the need to collect, process and make a proper use of information on all forms of relations between them and their customers.

\footnotetext{
${ }^{1}$ Grzegorz Lew, DSc, PhD, Eng, Associate Professor, Faculty of Management, Rzeszów University of Technology, al. Powstańców Warszawy 10, 35-959 Rzeszów phone: 17 743-25-85, e-mail: lewgrzes@prz.edu.pl.

Dr hab. inż. Grzegorz Lew, prof. PRz, Wydział Zarządzania, Politechnika Rzeszowska, al. Powstańców Warszawy 10, 35-959 Rzeszów, tel.: 17 743-25-85, e-mail: lewgrzes@ @rz.edu.pl.

${ }^{2}$ L. Drabik, A. Kubiak-Sokół, E. Sobol, L. Wiśniakowska (red.), Słownik języka polskiego, PWN, Warszawa 2009, p. 325.

3 J. Altkorn, T. Kramer (ed.), Leksykon marketingu, PWE, Warszawa 1998, p. 115.

${ }^{4}$ K. Sedlak (ed.), Strategie w biznesie, Wydawnictwo Profesjonalnej Szkoły Biznesu, Kraków 1993, p. 84 .
} 
An ability to maintain long-term, profitable customer relationships is crucial for trading companies. Staying in long-term contact with our customers means continuously satisfying their changing needs over time. The need is defined as an objective property of an organism or a subjective feeling of absence ${ }^{5}$. The need is defined differently by J. O'Shaughnessy who defines it as a propensity to use or possess ${ }^{6}$.

Customer relations are the relationships between a trading company and its customers ${ }^{7}$. Authors of accounting studies view customer relations in a transactional context, i.e. as the sum of all sales transactions whose financial effect is revenue ${ }^{8}$. However, this perception of customer relations is too narrow and significantly distorts the ability to manage them.

In today's business management, more and more attention is paid to the importance of long-term, effective customer relationships. H. Mintzberg believes that establishing and maintaining external contacts and creating support groups outside the company are activities to which managers must devote a lot of time ${ }^{9}$. In theory and practice, the trend described as customer relationship management (CRM) has developed ${ }^{10}$. Customer relationship management is "the basis of a business philosophy focused on analyzing, planning and controlling customer relationships using the latest information and communication technologies"11. Sales departments do not focus on maximizing the profitability of individual transactions. The key problem is considered to be customer profitability, i.e. profitability in the long run, and creating value for the customer.

\section{VALUE FOR THE CUSTOMER}

In creating value for the client, an enterprise needs to take appropriate actions which will contribute to increasing value for the client or satisfying the needs of the enterprise ${ }^{12}$. The concept of creating value for the customer stems from the theory of demand in economy; goods (products) are perceived by customers as a set of features, i.e. quality, functionality, physicochemical form, price and others, which can be freely shaped to meet their expectations. Customers may to different degrees prefer these characteristics, which allows companies differentiating their sales policies for different customers or groups of customers ${ }^{13}$. As a result, companies can take various measures to create a value for the customers of a product so that it is recognized by them. These activities, although carried

5 J. Reykowski, Z zagadnień psychologii motywacji, Warszawa 1970, p. 91-93.

6 J. O'Shaughnessy, Dlaczego ludzie kupuja, Warszawa 1994.

7 see: J. Otto, Marketing relacji. Koncepcja i stosowanie, Warszawa 2004; I. Dembińska-Cyran,

J. Hołub-Iwan, J. Perenc, Zarządzanie relacjami z klientami, Warszawa 2004.

8 see: E.A. Hendriksen, M.F. van Breda, Teoria rachunkowości, Warszawa 2002.

9 H. Mintzberg, Zarzadzanie, Warszawa 2012, p. 97.

${ }^{10}$ For more: W. Wereda, Zarządzanie relacjami z klientem (CRM) a postępowanie nabywców na rynku ustug, Difin, Warszawa 2009; J. Dyché, CRM relacje z klientami, Gliwice 2002; E.K. Kevork, A.P. Vrechopoulos, CRM literature: conceptual and functional insights by keyword analysis, ,Marketing Intelligence \& Planning” 2009, Vol. 27.

${ }^{11}$ B. Dobiegała-Korona, Wartość klienta [in:] Metody wyceny spótki. Perspektywa klienta i inwestora, red. M. Panfil, A. Szablewski, Warszawa 2006, p. 82.

12 J.A. Miller, współpraca K. Pniewski, M. Polakowski, Zarządzanie kosztami działań, Warszawa 2000, p. 203.

${ }^{13}$ B. Nita, Analiza kosztów tańcucha wartości [in:] Strategiczne zarzadzanie kosztami, ed. E. Nowak, Kraków 2006; P. Szczypa, Rachunkowość zarządcza: klucz, do sukcesu, Warszawa 2008. 
out in order to optimize revenues from sales, will, of course, generate specific costs. These costs will largely depend on the type of activities used to achieve the objectives.

In order to identify the activities that contribute most to gaining and maintaining a competitive advantage, it is necessary to analyze them. In analyzing the activities, a distinction should be made between those which create added value for customers and those which do not. The company's operations are primarily carried out for three reasons ${ }^{14}$ :

- are necessary to meet the needs and expectations of customers,

- are needed to maintain the company as a whole,

- they confer an advantage on a company.

By offering goods ${ }^{15}$ to the customer, the company creates a commercial service through its activities in the internal value chain. Since every activity in the company should be subordinated to the creation of the value of the company, the companies must be able to identify those activities which create this value. As customers are the main source of value creation for the company, these activities should be seen in the context of activities that create or do not create customer perceived value (CPV). These links are illustrated in Figure 1.

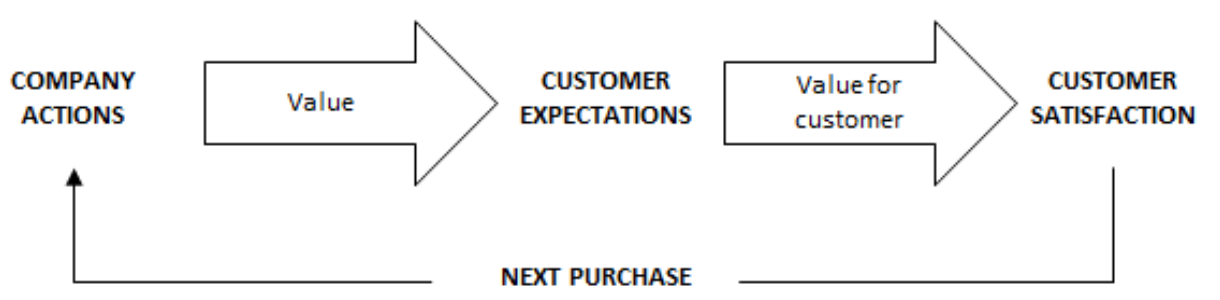

Figure 1. Links between business activities and customer value

Source: authors' own research.

An action which creates value is one which increases the value of a commercial service to the customer or which is necessary for the operation of the commercial company. The value for the customers is perceived by them as a set of desirable characteristics that should characterize a commercial service. The basic component of this service is the product which these customers are interested in. The basic features of a commercial service that can potentially create the value for a customer include:

- quality of the offer and/or good,

- availability,

- reliability,

- price.

These features can be amplified or muted in various configurations to meet the needs of individual customers. The goods and accompanying services offered by commercial companies should constitute an offer which maximizes the value for money for the customer, while maintaining an acceptable level of cost for those services.

${ }^{14}$ E.J. Blocher, D.E. Stout, G. Cokins, Cost Management. A Strategic Emphasis, $5^{\text {th }}$ Edition, New York 2010, p. 139.

15 Goods are purchased, by a trading unit, from suppliers with a view to resale - M. Klimas, Podręczna encyklopedia rachunkowości, Warszawa 2000, p. 639. 
When identifying the activities that create value for the customer, it is a problem to estimate the value that customers assign to the commercial service ${ }^{16}$. Value for the customer can be defined as the willingness of the buyer to pay the amount for the goods and accompanying services offered by the company. The result of this valuation is that the relationship between the company and the customer is bilateral and that the value for the customer is the difference between the benefits received and the price paid by the customer.

Activities that create value for the customer are, therefore, the activities that significantly influence the way the customer perceives a commercial service, and in particular concern its quality and usefulness. The activities that can be considered as increasing value for the customer include those that ${ }^{17}$ :

- are necessary or desirable to satisfy a sense of customer satisfaction,

- improve the quality of the commercial service,

- if they are performed, the customer is willing to pay for them,

- are an essential part of the commercial service process and cannot therefore be eliminated,

- are carried out in order to solve or remove problems related to the quality assurance of commercial services,

- are made on special order of the customer,

- could be done to a greater extent if time allowed.

Activities that do not create value for the customer are activities that consume time ineffectively, unnecessarily increase resource consumption, do not increase customer satisfaction, and do not add value to goods or commercial services from a customer's perspective. Therefore, activities that do not create value include those that ${ }^{18}$ :

- can be eliminated without affecting the quality of the commercial service,

- cause damage and loss,

- are performed as a result of inefficiencies in other activities,

- are duplicated at different locations of the company,

- are performed due to the unsatisfactory quality of other activities,

- are performed as a result of requests from dissatisfied customers,

- they would be implemented to a lesser extent, if only possible.

Each manager should treat the creation of value for the client as a tool to achieve the main goal of conducting business activity, which is to maximize the financial result in the short term and to maximize the value of the company in the long term.

Activities that create value for customers should be considered not only in terms of the costs they generate but also, and above all, in terms of the revenues they generate. Thanks to this reasoning, it should be assumed that the performance of activities that create value for the customer contributes to the growth of the financial result generated from sales. Value creation activities should be assumed to increase customer satisfaction. In such a case, activities that do not contribute to the increase of the financial result, for example in the case of generating costs without increasing revenues, should be considered as not creating value.

\footnotetext{
${ }^{16}$ In this case, defined as: the specific good and the accompanying pre- and after-sales activities.

${ }^{17}$ E.J. Blocher, D.E. Stout, G. Cokins, Cost Management..., p. 139-141.

18 Ibidem, p. 139-141.
} 
Customer relations in accounting are presented primarily as transactional relationships. Currently, the view of customer relations goes far beyond transactional treatment. Customer relations are seen as the whole of the relationship between a company and its customers. L. Berry described this in the 1980s as "creating, maintaining and enriching customer relationships"19. According to T. Sztucki, the concept of customer relations is a concept of management and market activities, according to which the market effectiveness of companies depends on establishing partnership relations with market participants. This concept assumes building loyalty relations with customers and strategic alliances with business partners ${ }^{20}$.

From an accounting perspective, it is important that the modern view of customer relations presupposes its versatility. Relationships with individual customers are not limited to individual transactions, but are limited to a whole series of transactions over the entire life cycle of the customer within the company. Customer relations develop not only as a result of activities undertaken in various functional areas of the business, but also as a result of activities undertaken by the customers themselves. Apart from customers, these activities are also influenced by the rest of the company's environment, e.g. competitors, potential customers, local communities, media, legal regulations, environment protection aspects.

The complexity of customer relations, despite their versatility, can be captured in three perspectives of management analyses. These include:

- the customer perceived value (CPV) concept,

- the customer lifetime value (CLV) concept,

- the concept of co-creation by the company and the customer acting in a specific environment.

The first concept focuses on the identification and valuation of the value that a trading company can offer a customer, so that from his perspective, the purchase in the company will bring the greatest possible benefits to the customer. The second perspective emphasizes an ability to determine the value of the customer for the company in the long term, throughout the entire life cycle of the customer. The third concept, in turn, uses the so-called stakeholder theory defined by R. E. Freeman ${ }^{21}$ in 1984, which served to explain the changes taking place in the systems of enterprise management. This theory also contributed to the development of the concept of customer relations. The place of customer relations in the stakeholder theory is shown in Figure 2.

According to this theory, although customer relations are of key importance for a company's business, it must also take into account other stakeholders in its operations.

Companies should change their perception of their relationship with their environment. The burden of customer contact must be placed on building sustainable customer relationships ${ }^{22}$. Of course, the basic measure of these relations will be the economic measure. The basic differences between the transactional approach and building lasting relations with customers are presented in Table 1.

\footnotetext{
19 J. Otto, Marketing relacji. Koncepcja i stosowanie, Warszawa 2004, p. 41.

20 T. Sztucki, Encyklopedia marketingu, Warszawa 1998, p. 171.

${ }^{21}$ R.E. Freeman, Strategic Management. A Stakeholder Approach, Boston 1984.

22 E.K. Geffroy, Clienting. Jedyne, co przeszkadza to klient, Warszawa 1996, p. 115.
} 


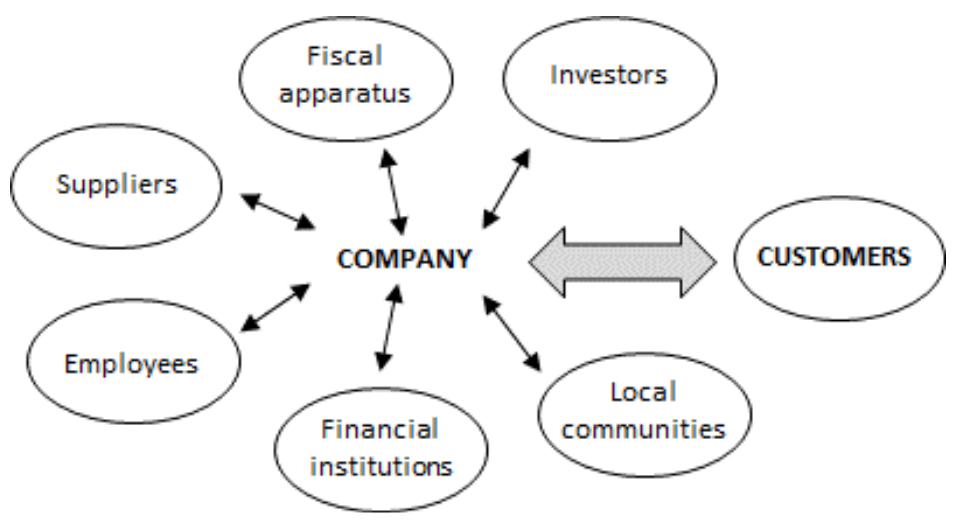

Figure 2. Relations with customers and other stakeholders

Source: author's own research based on: T. Donaldson, L.E. Preston, The Stakeholder theory of the Corporation. Concepts, Evidence and Implications, "Academy of Management Review" 1995, Vol. 20, No. 1, p. 69.

Table 1. Comparison of transactional and permanent customer relationships

\begin{tabular}{|l|l|}
\hline \multicolumn{1}{|c|}{ Transactional relationships } & \multicolumn{1}{c|}{ Permanent relationships } \\
\hline Focus on a single sale & Focus on customer retention \\
\hline $\begin{array}{l}\text { Most important - characteristics of the product } \\
\text { (good) }\end{array}$ & $\begin{array}{l}\text { Most important - customer benefits from the } \\
\text { purchase }\end{array}$ \\
\hline Short-term perspective for action & Long-term perspective for action \\
\hline Customer service not very important & Customer service is very important \\
\hline Incidental contact with a customer & Continuous contact with the customer \\
\hline Limited customer loyalty & High customer loyalty \\
\hline
\end{tabular}

Source: own based on: A. Payne, Marketing ustug, Warszawa 1996, p. 53.

It should be noted that building lasting relationships with customers has an impact on:

- implementation of the customer-oriented strategy of the company,

- optimization of the internal as well as the external value chain,

- creating new value for customers,

- giving a central role to individual customers not only in buying and selling transactions but also in determining the type of benefit that the customer expects from the relationship with the trading company, so that value is created together with the customer and not for the customer,

- the need to design and adapt activities, communication tools, employee training, implementation of innovative technologies so that they create benefits expected by the customer,

- the need for continuous communication with customers, often online, 
- a change in the procedure for assessing customer profitability on the basis of the total value of contacts made throughout the customer's life cycle, rather than on the basis of individual transactions.

All the activities of the trading company, including its customer relations, are the result of compromise decisions that address the basic and additional objectives of the company.

The economic benefits received from customers in a continuing relationship are not limited to transactional benefits but also relate to intangible assets ${ }^{23}$, because the sum of the customer relationships includes both the benefits and the costs to the trading enterprise and the customers.

J.L. Heskett, W.E. Sasser Jr., L.A. Schlesinger, in their research and experience, found that maintaining long-term customer relationships contributes to the continuous improvement of the profitability of these customers ${ }^{24}$.

The increase in the profitability of customers along with the duration of these relationships is primarily related to the economies of scale that arise when the customer determines, after an initial period of cooperation, that the choice of supplier is accurate. In such a situation, he usually obtains all his purchases of a given product or assortment from them. In order to increase the profitability of a regular customer, it will be possible to reduce the costs of its service by personalizing actions only on the actual expectations of the customer. This makes it possible to resign from activities that this customer does not need. A satisfied customer in whispered marketing passes this information on to other potential customers of the company, which also contributes, although difficult to quantify fully, to improving its profitability. The company may also use its image to attract new customers, particularly if it can offer its customers a price premium based on a comparison of its brand with the best on the market.

Of course, one must be aware that the implementation of profitable customer relations does not depend only on the duration of customer relations, but first of all on the type of customers with whom they are created. P. Kotler states that it is an art to gain, maintain and develop relationships with profitable customers ${ }^{25}$. Therefore, it is important that companies focus their activities on profitable customers, undertake efforts to transform unprofitable customers into profitable ones and try to get rid of unprofitable customers, with whom it is no longer profitable to invest.

\section{THE CUSTOMER VALUE CREATION MODEL}

The key role in the projection of the appropriate value for the customer is the customer's satisfaction with the relationship with the given supplier. Satisfaction is after-purchase evaluation of the quality of goods or services, which is shaped on the basis of beforepurchase customer expectations ${ }^{26}$. Customer satisfaction will be a key determinant of establishing lasting relationships with the customer and shaping the value for the customer. Customer satisfaction is not constant throughout the relationship. Customer perceptions will

\footnotetext{
${ }^{23}$ These include, for example, recommendations, gaining experience, learning from each other, i.e. benchmarking in a broad sense.

${ }^{24}$ J.L. Heskett, W.E. Sasser Jr., L.A. Schlesinger, The Service Profit Chain: How Leading Companies Link Profit and Growth to Loyalty, Satisfaction, and Value., New York 1997, p. 64.

${ }^{25}$ P. Kotler, K.L. Keller, Marketing, Poznań 2012, p. 166.

${ }^{26}$ Ibidem, p. 140.
} 
change by comparing expectations based on previous experience or individual requirements with the actual situation when purchasing from the supplier (Figure 3 ). The individuality of customer satisfaction perception is an important cost driver in the process of creating value for the customer.

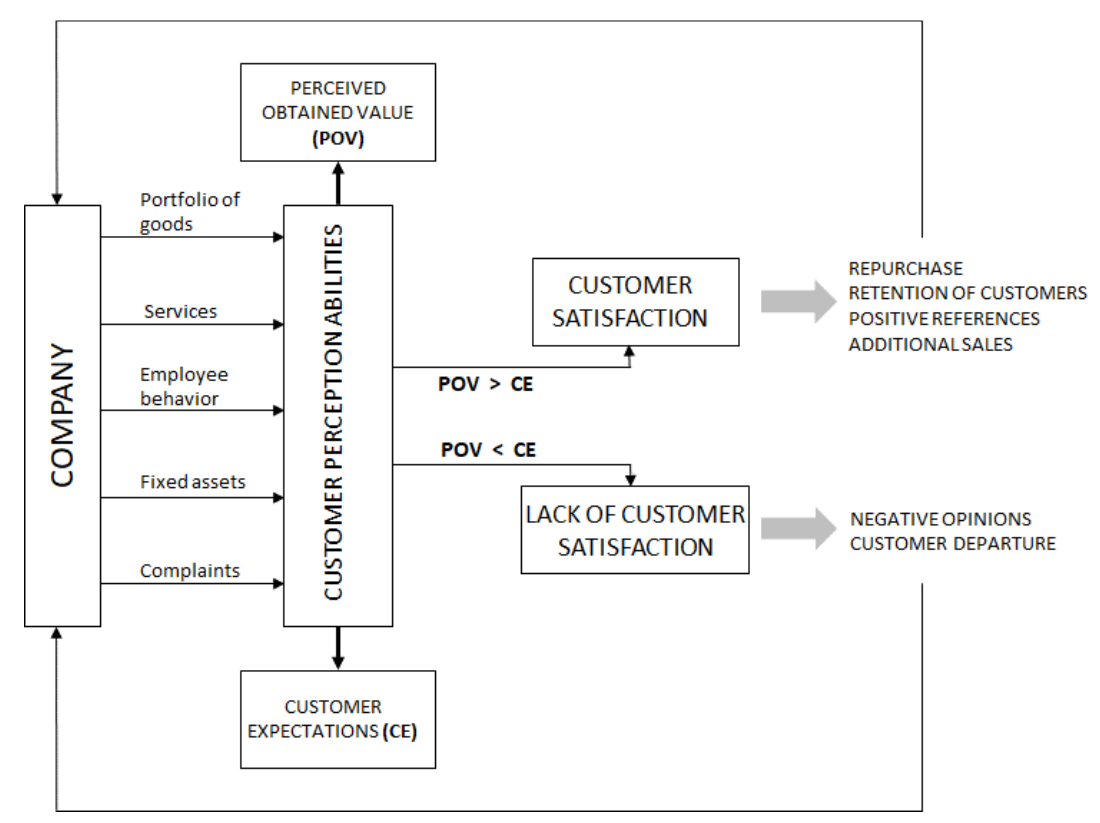

Figure 3. General model for creating value for a customer in a trading firm

Source: own based on: A.K. Rai, Customer Relationship Management. Concepts and Cases, New Delhi 2013, p. 58.

Different customer perceptions of satisfaction make it difficult to predict which actions will prove successful in a particular case ${ }^{27}$. The level of satisfaction depends on the objective characteristics of the trading offer and on the customer's past experience and requirements. These factors influence the perception of goods and services by the customer, shape the level of his satisfaction and, consequently, the value for the customer.

\section{CONCLUSION}

Profitable customer relationships are key to the ability of companies to continue and grow their businesses. Keeping a profitable customer is a key factor for the success of these companies. Caring for long-term, profitable customer relationships is critical. This is particularly important where the cost of acquiring a new customer is high, and resigning

27 J. Lisowski, Wskaźnik satysfakcji klienta, „Ekonomika i Organizacja Przedsiębiorstwa” 1999, nr 5, 25. 
from cooperation with the supplier, for the customer, does not mean incurring additional costs.

It should be remembered that all activities aimed at maintaining or improving customer relations entail certain costs. However, the focus of companies on customer value activities increases the profitability of customer relationships. Therefore, an increase in such costs is desirable, provided that the necessary condition is met, i.e. a more dynamic increase in revenues from customer relations.

The next stages of the research should be to conduct research aimed at improving the estimation of costs of customer relations ${ }^{28}$. The revenues that trading companies generate from their customer relations are relatively easy to identify. The ability to identify and value customer relationship costs is different.

Of course, various tools may be helpful in building profitable relations with customers, such as creating shopping groups ${ }^{29}$, using modern cost accounts ${ }^{30}$. In any case, however, it will be the customer who decides whether or not to purchase from the supplier, and this will determine the value to the customer that he or she will perceive when using the commercial service of that supplier.

\section{REFERENCES}

Altkorn J., Kramer T., (red.), Leksykon marketingu, PWE, Warszawa 1998.

Blocher E.J., Stout D.E., Cokins G., Cost Management. A Strategic Emphasis, $5^{\text {th }}$ Edition, McGraw-Hill/Irwin, New York 2010.

Bochenek M., Rachunek kosztów docelowych jako nowoczesne narzędzie rachunkowości zarzadczej [w:] Rachunkowość instrumentem zarządzania jednostek gospodarczych i instytucji, red. G. Lew, Oficyna Wydawnicza Politechniki Rzeszowskiej, Rzeszów 2015.

Chłodnicka H., Zimon G., Analiza kosztów w przedsiębiorstwach tworzacych grupy zakupowe, „Finanse, Rynki Finansowe, Ubezpieczenia” 2013, z. 765/61, Wydawnictwo Naukowe Uniwersytetu Szczecińskiego.

Dembińska-Cyran I., Hołub-Iwan J., Perenc J., Zarządzanie relacjami z klientami, Difin, Warszawa 2004.

Dobiegała-Korona B., Wartość klienta [w:] Metody wyceny spótki. Perspektywa klienta $i$ inwestora, red. M. Panfil, A. Szablewski, Poltex, Warszawa 2006.

Donaldson T., Preston L. E., The Stakeholder theory of the Corporation. Concepts, Evidence and Implications, "Academy of Management Review" 1995, Vol. 20, No. 1 (January).

Drabik L., Kubiak-Sokół A., Sobol E., Wiśniakowska L., (red.), Słownik języka polskiego, PWN, Warszawa 2009.

${ }^{28}$ G. Lew, Rachunek kosztów klienta w zarzadzaniu przedsiębiorstwem handlowym, Rzeszów 2015.

${ }^{29}$ H. Chłodnicka, G. Zimon, Analiza kosztów w przedsiębiorstwach tworzacych grupy zakupowe, „Finanse, Rynki Finansowe, Ubezpieczenia” 2013, z. 765/61.

${ }^{30}$ M. Bochenek, Rachunek kosztów docelowych jako nowoczesne narzędzie rachunkowości zarzadczej [w:] (red.), Rachunkowość instrumentem zarządzania jednostek gospodarczych i instytucji, red. G. Lew, Rzeszów 2015; A. Lew, Zarządcze walory tradycyjnego rachunku kosztów [w:] Instrumenty zarzadzania kosztami i dokonaniami, red. E. Nowak, M. Nieplowicz, Prace Naukowe UE we Wrocławiu nr 252, Wrocław 2012; G. Lew, Ogólny model rachunku kosztów klienta, "Humanities and Social Sciences", Quarterly, Vol. XXI, Research Journal 23 (April-June -2/2016), Publishing House of Rzeszow University of Technology, Rzeszów 2016. 
Dyché J., CRM relacje z klientami, Helion, Gliwice 2002.

Freeman R. E., Strategic Management. A Stakeholder Approach, Pitman, Boston 1984.

Geffroy E. K., Clienting. Jedyne, co przeszkadza to klient, Placet, Warszawa 1996.

Hendriksen E.A., van Breda M.F., Teoria rachunkowości, Wydawnictwo Naukowe PWN, Warszawa 2002.

Heskett J.L., Sasser W.E. Jr., Schlesinger L.A., The Service Profit Chain: How Leading Companies Link Profit and Growth to Loyalty, Satisfaction, and Value, The Free Press, New York 1997.

Kevork E.K., Vrechopoulos A.P., CRM literature: conceptual and functional insights by keyword analysis, Marketing Intelligence \& Planning 2009, Vol. 27.

Klimas M., Podręczna encyklopedia rachunkowości, Poltext, Warszawa 2000.

Kotler P., Keller K.L., Marketing, Rebis, Poznań 2012.

Kotler P., Kotler o marketingu. Jak kreować i opanowywać rynki, Wydawnictwo Profesjonalnej Szkoły Biznesu, Kraków 1999.

Lew A., Zarzadcze walory tradycyjnego rachunku kosztów [w:] Instrumenty zarządzania kosztami i dokonaniami, red. E. Nowak, M. Nieplowicz, Prace Naukowe UE we Wrocławiu nr 252, Wrocław 2012.

Lew G., Ogólny model rachunku kosztów klienta, "Humanities and Social Sciences", Quarterly, Vol. XXI, Research Journal 23 (April-June - 2/2016), Publishing House of Rzeszow University of Technology, Rzeszów 2016.

Lew G., Rachunek kosztów klienta w zarzadzaniu przedsiębiorstwem handlowym, Oficyna Wydawnicza Politechniki Rzeszowskiej, Rzeszów 2015.

Lisowski J., Wskaźnik satysfakcji klienta, „Ekonomika i Organizacja Przedsiębiorstwa” 1999, nr 5.

Miller J.A., współpraca K. Pniewski, M. Polakowski, Zarządzanie kosztami działań, WIG-Press, Warszawa 2000.

Mintzberg H., Zarządzanie, Wolters Kluwer business, Warszawa 2012.

Nita B., Analiza kosztów tańcucha wartości [w:] Strategiczne zarządzanie kosztami, red. E. Nowak, Oficyna Ekonomiczna, Kraków 2006.

O’Shaughnessy J., Dlaczego ludzie kupuja, Państwowe Wydawnictwo Ekonomiczne, Warszawa 1994.

Otto J., Marketing relacji. Koncepcja i stosowanie, C.H. Beck, Warszawa 2004.

Payne A., Marketing ustug, PWE, Warszawa 1996.

Rai A.K., Customer Relationship Management. Concepts and Cases, PHI Learning Private Limited, New Delhi 2013.

Reykowski J., Z zagadnień psychologii motywacji, Państwowe Zakłady Wydawnictw Szkolnych, Warszawa 1970.

Sedlak K., (red.), Strategie w biznesie, Wydawnictwo Profesjonalnej Szkoły Biznesu, Kraków 1993.

Szczypa P., Rachunkowość zarzadcza: klucz do sukcesu, CeDeWu, Warszawa 2008.

Sztucki T., Encyklopedia marketingu, Placet, Warszawa 1998.

Wereda W., Zarzadzanie relacjami z klientem (CRM) a postępowanie nabywców na rynku ustug, Difin, Warszawa 2009. 


\section{RELACJE Z KLIENTAMI W BUDOWANIU WARTOŚCI DLA KLIENTA W PRZEDSIĘBIORSTWACH HANDLOWYCH}

W każdym przedsiębiorstwie klient odgrywa kluczową rolę. Jest on głównym „dostarczycielem" przychodów. Od odpowiednich relacji z klientami uzależniona jest rentowności prowadzonej działalności gospodarczej przez konkretne przedsiębiorstwo. Zadaniem rachunkowości zarządczej w przedsiębiorstwie jest wypracowanie takiej metody szacowania rentowności klientów, aby wspierała ona decyzje zarządzających w kształtowaniu rentownych, długoterminowych relacji z klientami. Narzędzie pomagające określić wymagania klientów to wartości dla klienta. Celem opracowania jest przedstawienie koncepcji wartości dla klienta w przedsiębiorstwach handlowych. Przy opracowaniu artykułu wykorzystano krytyczny przegląd literatury, metodę dedukcji oraz indukcji. Artykuł zawiera propozycje wykorzystania różnych zmiennych do określenia wartości dla klienta.

Słowa kluczowe: klient, wartość dla klienta, relacje.

DOI: $10.7862 /$ rz.2018.hss.76

Tekst złożono do redakcji: czerwiec $2018 \mathrm{r}$.

Tekst przyjęto do druku: grudzień 2018 r. 
